\title{
Front Matter: Volume 8106
}

, "Front Matter: Volume 8106," Proc. SPIE 8106, Nanoepitaxy: Materials and Devices III, 810601 (22 September 2011); doi: 10.1117/12.906480

SPIE Event: SPIE NanoScience + Engineering, 2011, San Diego, California, United SPIE. States 


\section{PROCEEDINGS OF SPIE}

\section{Nanoepitaxy: Materials and Devices III}

Nobuhiko P. Kobayashi

A. Alec Talin

M. Saif Islam

Editors

24-25 August 2011

San Diego, California, United States

Sponsored and Published by

SPIE 
The papers included in this volume were part of the technical conference cited on the cover and title page. Papers were selected and subject to review by the editors and conference program committee. Some conference presentations may not be available for publication. The papers published in these proceedings reflect the work and thoughts of the authors and are published herein as submitted. The publisher is not responsible for the validity of the information or for any outcomes resulting from reliance thereon.

Please use the following format to cite material from this book:

Author(s), "Title of Paper," in Nanoepitaxy: Materials and Devices III, edited by

Nobuhiko P. Kobayashi, A. Alec Talin, M. Saif Islam, Proceedings of SPIE Vol. 8106 (SPIE, Bellingham, WA, 2011) Article CID Number.

ISSN 0277-786X

ISBN 9780819487162

Published by

SPIE

P.O. Box 10, Bellingham, Washington 98227-0010 USA

Telephone +1 3606763290 (Pacific Time) · Fax +1 3606471445

SPIE.org

Copyright (C) 2011, Society of Photo-Optical Instrumentation Engineers

Copying of material in this book for internal or personal use, or for the internal or personal use of specific clients, beyond the fair use provisions granted by the U.S. Copyright Law is authorized by SPIE subject to payment of copying fees. The Transactional Reporting Service base fee for this volume is $\$ 18.00$ per article (or portion thereof), which should be paid directly to the Copyright Clearance Center (CCC), 222 Rosewood Drive, Danvers, MA 01923. Payment may also be made electronically through CCC Online at copyright.com. Other copying for republication, resale, advertising or promotion, or any form of systematic or multiple reproduction of any material in this book is prohibited except with permission in writing from the publisher. The CCC fee code is 0277-786X/11/ \$18.00.

Printed in the United States of America.

Publication of record for individual papers is online in the SPIE Digital Library.

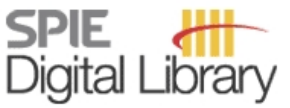

SPIEDigitalLibrary.org

Paper Numbering: Proceedings of SPIE follow an e-First publication model, with papers published first online and then in print and on CD-ROM. Papers are published as they are submitted and meet publication criteria. A unique, consistent, permanent citation identifier (CID) number is assigned to each article at the time of the first publication. Utilization of CIDs allows articles to be fully citable as soon as they are published online, and connects the same identifier to all online, print, and electronic versions of the publication. SPIE uses a six-digit CID article numbering system in which:

- The first four digits correspond to the SPIE volume number.

- The last two digits indicate publication order within the volume using a Base 36 numbering system employing both numerals and letters. These two-number sets start with 00, 01, 02, 03, 04, $05,06,07,08,09,0 A, 0 B \ldots 0 Z$, followed by 10-1Z, 20-2Z, etc.

The CID number appears on each page of the manuscript. The complete citation is used on the first page, and an abbreviated version on subsequent pages. Numbers in the index correspond to the last two digits of the six-digit CID number. 


\section{Contents}

$\checkmark$ Conference Committee

\section{SESSION 1 NANOWIRES I}

810603 Nanowire based heterostructures: fundamental properties and applications (Invited Paper) [8106-03]

M. Heiss, C. Colombo, A. Fontcuberta i Morral, Ecole Polytechnique Fédérale de Lausanne (Switzerland)

\section{SESSION 2 NANOEPITAXIAL SYNTHESIS I}

810608 Copper oxide thin-flim and nanowire for e-textile applications (Invited Paper) [8106-08] J.-W. Han, NASA Ames Research Ctr. (United States); A. Lohn, N. P. Kobayashi, Univ. of California, Santa Cruz (United States); M. Meyyappan, NASA Ames Research Ctr. (United States)

\section{SESSION 3 NANOEPITAXIAL MATERIALS: DEVICE APPLICATIONS I}

$81060 \mathrm{C}$ Integrated amplifying nanowire FET for surface and bulk sensing (Invited Paper) [8106-13] C. O. Chui, K.-S. Shin, Univ. of California, Los Angeles (United States)

\section{SESSION 4 NANOEPITAXIAL MATERIALS: DEVICE APPLICATIONS II}

8106 OG Metal oxide nanowire growth for nanotechnology-enhanced device applications (Invited Paper) [8106-17] M. M. Oye, J. Gacusan, O. Lenz, T. Ngo-Duc, J. M. Velazquez, E. Arreola, H. Jethani, M. Rohovie, B. Gigante, A. Kar, B. Kim, A. Hannon, A. Savvinov, Y. Lu, J. Li, M. Meyyappan, Univ. of California, Santa Cruz (United States) and NASA Ames Research Ctr. (United States)

$8106 \mathrm{OH}$ Synthesis of crystalline $\mathrm{ZnO}$ nanostructures on arbitrary substrates at ambient conditions (Invited Paper) [8106-18]

P. K. Vabbina, P. Nayyar, Florida International Univ. (United States); A. P. Nayak, A. M. Katzenmeyer, L. VJ, Univ. of California, Davis (United States); N. Pala, Florida International Univ. (United States); M. S. Islam, Univ. of California, Davis (United States); A. A. Talin, Sandia National Labs. (United States) 
8106 Ol Transport in fused InP nanowire device in dark and under illumination: Coulomb staircase scenario (Invited Paper) [8106-19]

T. Yamada, Santa Clara Univ. (United States) and Univ. of California, Santa Cruz (United States); H. Yamada, Univ. of California, San Diego (United States); A. J. Lohn, N. P. Kobayashi, Univ. of California, Santa Cruz (United States) and NASA Ames Research Ctr. (United States)

8106 OK Scanning photocurrent microscopy in single nanowire devices (Invited Paper) [8106-22] R. Graham, C. Miller, M. Triplett, D. Yu, Univ. of California, Davis (United States)

$8106 \mathrm{OL}$ Growth of $\mathrm{ZnO}$ nanowires on retroreflector microspheres and the resulting light channeling and plasmonic properties (Invited Paper) [8106-23]

S. M. Prokes, O. J. Glembocki, E. Cleveland, H. Qi, U.S. Naval Research Lab. (United States)

SESSION 6 NANOEPITAXIAL SYNTHESIS II

8106 0N Growth of ZnO-based nanorod heterostructures and their photonic device applications (Invited Paper) [8106-25]

J. Yoo, S. T. Picraux, Los Alamos National Lab. (United States); G.-C. Yi, Seoul National Univ. (Korea, Republic of)

8106 OP Compositional grading of $\ln _{\mathbf{x}} \mathbf{G a}_{1-x} A s / G a A s$ tunnel junctions enhanced by ErAs nanoparticles [8106-27]

R. Salas, E. M. Krivoy, A. M. Crook, H. P. Nair, S. R. Bank, The Univ. of Texas at Austin (United States)

\section{SESSION $7 \quad$ NANOEPITAXIAL SYNTHESIS III}

$81060 Q \quad$ Nanocomposites for thermoelectric power generation: rare-earth metal monoantimonide nanostructures embedded in InGaSb and InSbAs ternary alloys [8106-28]

K. J. Norris, Univ. of California, Santa Cruz (United States) and NASA Ames Research Ctr. (United States); T. Onishi, Univ. of California, Santa Cruz (United States); A. J. Lohn, N. Padgaonkar, V. Wong, Univ. of California, Santa Cruz (United States) and NASA Ames Research Ctr. (United States); E. Coleman, G. S. Tompa, Structured Materials Industries Inc. (United States); N. P. Kobayashi, Univ. of California, Santa Cruz (United States) and NASA Ames Research Ctr. (United States)

8106 OR Growth of semimetallic ErAs films epitaxially embedded in GaAs [8106-29]

A. M. Crook, H. P. Nair, J. H. Lee, D. A. Ferrer, D. Akinwande, S. R. Bank, The Univ. of Texas at Austin (United States)

\section{SESSION 8 NANOWIRES II}

$81060 \mathrm{X}$ Indium phosphide nanowires integrated directly on carbon fibers [8106-35] A. J. Lohn, Univ. of California, Santa Cruz (United States) and NASA Ames Research Ctr. (United States); T. J. Longson, Univ. of California, Santa Cruz (United States); N. P. Kobayashi, Univ. of California, Santa Cruz (United States) and NASA Ames Research Ctr. (United States)

Author Index 


\title{
Conference Committee
}

\author{
Symposium Chairs
}

David L. Andrews, University of East Anglia Norwich (United Kingdom)

James G. Grote, Air Force Research Laboratory (United States)

\section{Conference Chairs}

Nobuhiko P. Kobayashi, University of California, Santa Cruz (United States)

A. Alec Talin, National Institute of Standards and Technology (United States)

M. Saif Islam, University of California, Davis (United States)

Program Committee

Kristine A. Bertness, National Institute of Standards and Technology (United States)

Albert V. Davydov, National Institute of Standards and Technology (United States)

Shadi A. Dayeh, Los Alamos National Laboratory (United States)

Supratik Guha, IBM Thomas J. Watson Research Center (United States)

Jung Han, Yale University (United States)

Chennupati Jagadish, The Australian National University (Australia)

Mutsumi Kimura, Ryukoku University (Japan)

Francois Leonard, Sandia National Laboratories, California (United States)

Takhee Lee, Gwangju Institute of Science and Technology (Korea, Republic of)

Marina S. Leite, California Institute of Technology (United States)

Samuel S. Mao, Lawrence Berkeley National Laboratory (United States) Sanjay Mathur, Universität zu Köln (Germany)

Samuel T. Picraux, Los Alamos National Laboratory (United States) Sharka M. Prokes, U.S. Naval Research Laboratory (United States) Zhifeng Ren, Boston College (United States)

Atsuhito Sawabe, Aoyama Gakuin University (Japan)

A. Fred Semendy, U.S. Army Research Laboratory (United States) Loucas Tsakalakos, GE Global Research (United States) Emanuel Tutuc, The University of Texas at Austin (United States) Lionel Vayssieres, National Institute for Materials Science (Japan) Deli Wang, University of California, San Diego (United States) George T. Wang, Sandia National Laboratories (United States) 
Session Chairs

1 Nanowires I

Nobuhiko P. Kobayashi, University of California, Santa Cruz

(United States)

2 Nanoepitaxial Synthesis I

A. Alec Talin, National Institute of Standards and Technology (United States)

3 Nanoepitaxial Materials: Device Applications I

Francois Leonard, Sandia National Laboratories, California (United States)

$4 \quad$ Nanoepitaxial Materials: Device Applications II

Joan M. Redwing, The Pennsylvania State University (United States)

5 Novel Characterization for Nanoepitaxial Materials

M. Saif Islam, University of California, Davis (United States)

Priyalal S. Wijewarnasuriya, U.S. Army Research Laboratory (United States)

6 Nanoepitaxial Synthesis II

Daniel E. Perea, Los Alamos National Laboratory (United States)

$7 \quad$ Nanoepitaxial Synthesis III

Sharka M. Prokes, U.S. Naval Research Laboratory (United States)

8 Nanowires II

Nobuhiko P. Kobayashi, University of California, Santa Cruz (United States) 